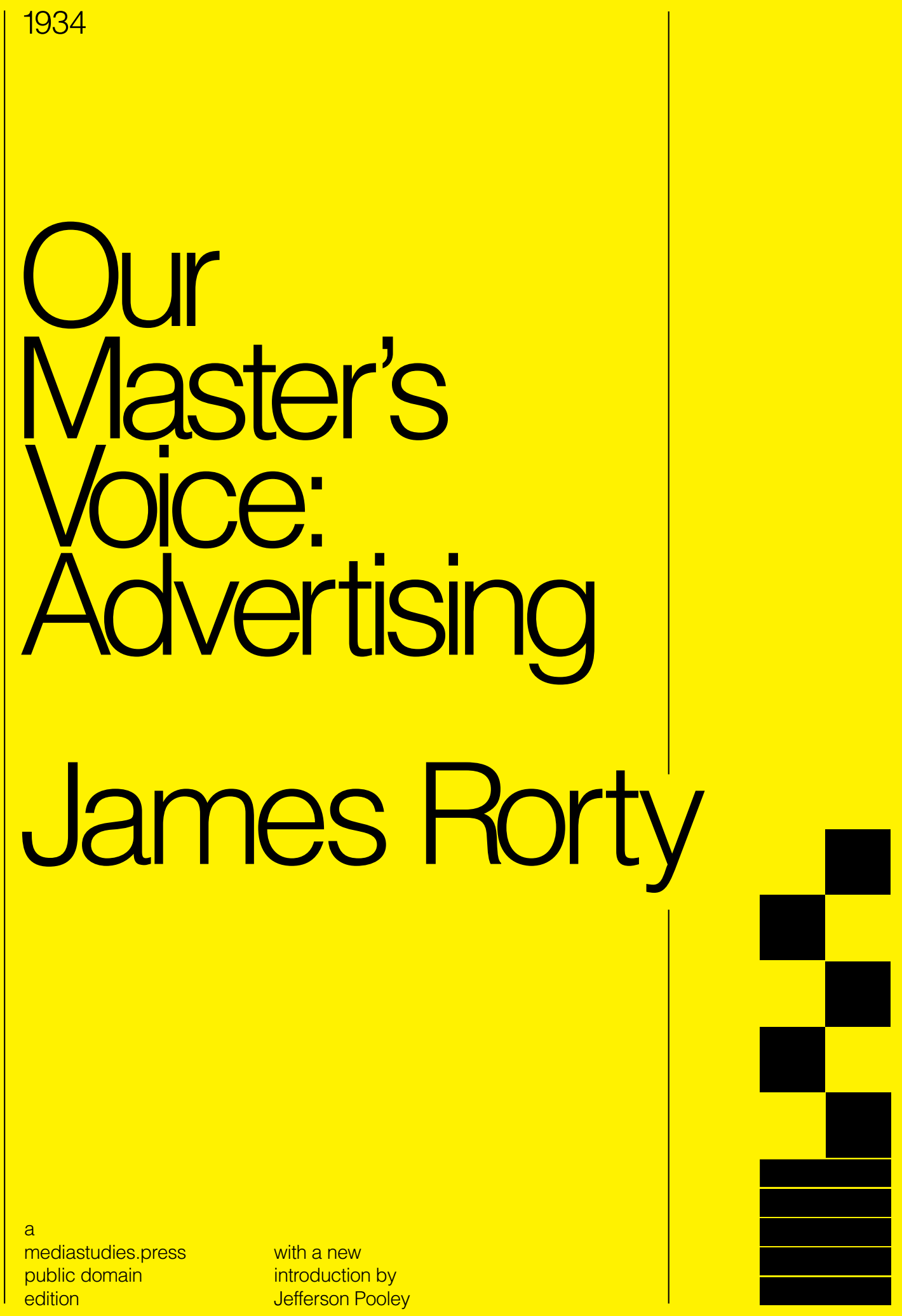




\section{James Rorty}

OUR MASTER'S VOICE

ADVERTISING 
Our Master's Voice: Advertising, originally published in 1934 by the JOHN DAY COMPANY, is in the public domain.

Published by mediastudies.press in the PUblic domain series

mediastudies.press I 414 W. Broad St., Bethlehem, PA 18018, USA

New materials are licensed under a Creative Commons Attribution-Noncommercial 4.o (CC BY-NC 4.O)

COVER DeSIGN: Mark McGillivray

COPY EDITING: Petra Dreiser

CREDIT FOR SCAN: Internet Archive, contributor Prelinger Library, 2006 upload

CREDit FOR LATeX template: Book design inspired by Edward Tufte, by The Tufte-LaTeX Developers

ISBN 978-1-951399-00-9 (print) I ISBN 978-1-951399-01-6 (ebook)

DOI $10.21428 / 3$ f8575cb.dbba9917

LIBRARY OF CONGRESS CONTROL NUMBER 202094177

Edition 1 published in October 2020 


\title{
JAMES RORTY'S VOICE: Introduction to the mediastudies.press edition
}

\author{
Jefferson Pooley
}

JAmes RoRTy announced his working knowledge of the trade in the opening paragraph of Our Master's Voice. Thirty years before, he reports, he had taken a job as a copywriter at an advertising agency in New York City. Though he preferred poetry and journalism, Rorty would continue to work intermittently in the ad business through the 1920s. Our Master's Voice, among the most penetrating critiques of advertising ever published, offers an insider's account: "I was an ad-man once," Rorty confesses. ${ }^{1}$

The book is Rorty's coming-to-terms with an institution he knew. But it neither chronicles his career nor gives an accounting of his impressions. Rather, it has a different, and surprising, character: Steeped in Rorty's leftist politics, Our Master's Voice presents advertising as the linchpin of a capitalist economy that it also helps justify.

Who dared take on the publication of Our Master's Voice in 1934? The John Day Company, a New York firm that had-amid a steep, Depression-era drop-off in books sales-published a series of fortyfive pamphlets notable for left-wing topics and authors. ${ }^{2}$ Our Master's Voice appeared in this spirit, though dense and promiscuous across twenty-six chapters and nearly four hundred pages in its original printing. It contains fictional interludes, detours through New Deal regulatory skirmishes, and a chapter devoted to Gillette's campaign against the beard.

Rorty made no apologies for the book's undisciplined format. Indeed, he disclaimed any academic purpose on the first page. Our Master's Voice was presented, he wrote, as journalism, "not as sociology." 3 Thus he granted himself license to code-switch, with what amounts to a short story slotted in as the fourth chapter, and doi

\footnotetext{
${ }^{1}$ Rorty, Our Master's Voice, ix. Page references are to the mediastudies.press edition; subsequent citations to the book are rendered as $O M V$.
}

\footnotetext{
${ }^{2}$ Rorty published his own thirty-twopage pamphlet, Order on the Air!, in The John Day Pamphlets series the same year. Rorty, Order on the Air! (New York: John Day Company, 1934). For an overview of Rorty's critique of commercial radio in particular, see Bruce Lenthall, Radio's America: The Great Depression and the Rise of Modern Mass Culture (Chicago: University of Chicago Press, 2007), 30-39; and Kathleen M. Newman, Radio Active: Advertising and Consumer Activism, 1935-1947 (Berkeley: University of California Press, 2004), 60-63.
} 
another devoted to composite portraits ("names, places and incidents have been disguised") of ad workers he had known. Nevertheless, the book abounds with dense and sophisticated analysis that is, by any measure, academic. One especially lengthy, chart-filled chapter, co-authored with his wife and another colleague, reports on a major empirical study of magazines. Throughout the book Rorty spars with the country's leading social scientists, quoting and then lacerating their work in what should undeniably be counted as academic debate.

More important, and despite its pastiche quality, the book presents a coherent and original theory of advertising. Its main tenet holds that the ad business can only be understood within the totality of the country's economy and culture. The alternative- to treat the business of publicity as a "carbuncular excrescence" - misses its centrality, its foundational place in American life. 4 Rorty thus insisted on a holistic approach-in conscious contrast to the bounded inquiries of his analytic rivals in the university system.

Rorty believed that the ad-man and his persuasive copy propped up American society-its capitalist economy, its culture of competitive emulation. 5 In effect, he makes his argument at two levels. The first is economic: All the billboards and radio spots, according to Rorty, provide the fuel that keeps people buying-the coal powering the country's merchandising juggernaut. American business would collapse without the ad-man's ventilation.

The book's second, complementary point is that the systeman exploitative one, in Rorty's view-relies on advertising for its ideological warrant. This claim emerges with greater subtlety, or at least erected around a series of sub-arguments, in the book's first few chapters. But the key takeaway suggests that advertising serves to ratify the prevailing American regime of class-stratified consumption. Rorty's former coworkers are, as it were, the master's voice.

Published into the Great Depression in 1934, the book agitated an already wounded publicity industry. It generated spirited reviews in the popular press, too. But social scientists-the sociologists and psychologists taking up the study of media and their audiences in small but growing numbers-ignored Our Master's Voice. They paid the book no heed when it was published, and media scholars have scarcely noticed it since.

\section{He Was an Ad-Man Once}

One reason for the neglect, then and since, lies with Rorty himself. He was no academic, and he didn't write like one. He was an intellectual — a poet, an essayist, a political journalist—in the orbit of
${ }^{3} \mathrm{OMV}$, ix.

${ }^{4} \mathrm{OMV}, 9$.

${ }^{5}$ I have adopted Rorty's genderexclusive language to remain faithful to the book's historical context, but do not otherwise condone the phrasing. 
the New York literary world. Like many of his peers, he embraced a radical worldview that, over the course of the 1920s, became more explicitly Marxist.

Rorty was born in 1890 in Middletown, New York, to an Irish immigrant, himself an aspiring poet, and his schoolteacher wife. The family ran a struggling dry goods business. ${ }^{6}$ We know nothing much of the young Rorty's life, but in high school he apprenticed at a local newspaper before attending Tufts College. After graduating in 1913, he took a copywriting post at the New York advertising agency $\mathrm{H}$. K. McCann, his first of three stints in the business. When the U.S. joined the war, Rorty enlisted in the Army ambulance corps, served in France, and earned a Distinguished Service Cross. ${ }^{7}$ He briefly returned to New York after the war, then moved to California, where he wrote poetry and covered the San Francisco literary and artistic scene for the Nation. In need of funds, he soon resumed work for advertising agencies, including a stint at McCann's San Francisco office. $^{8}$ A first marriage collapsed, but Rorty soon afterward met Winifred Raushenbush, then a research assistant to the Chicago sociologist Robert E. Park. ${ }^{9}$ Rorty and Raushenbush, the daughter of a prominent social gospel minister, fueled each other's radical politics on their return to New York in the mid-1920s. ${ }^{10}$ Both were steeped in the city's intellectual culture of so-called little magazines, including Marxist organs like the New Masses. ${ }^{11}$

During this period, working from a rural Connecticut cabin, Rorty reluctantly picked up advertising work a third time. Daniel Pope quotes Rorty's unpublished memoir: "I returned to my advertising vomit, prodding my fair white soul up and down Madison Avenue and offering it for sale to the highest bidder."12 Yet with the economy's collapse, Rorty was laid off in 1930. ${ }^{13}$ Like many other intellectuals in the wake of the Depression, Rorty turned to Marxist politics with new avidity. For a short stint, he even worked on behalf of the Communist Party's 1932 presidential slate, though he soon fell out with the party, which he never joined. In the cause of the recently exiled Leon Trotsky, Rorty's politics took on a decidedly anti-Stalinist cast. ${ }^{14}$ As Richard Rorty, Raushenbush and Rorty's only child and a future post-philosophical luminary, recounted in a memoir, "my parents had been classified by the Daily Worker as 'Trotskyites,' and they more or less accepted the description." 15

The Hitler-Stalin Pact of 1939 stiffened Rorty's anti-Soviet posture. By then his radical ardor had also cooled, and he began to endorse, for the first time, New Deal interventions like the Tennessee Valley Authority. In the war years his freelance writing, which he assiduously continued to produce for a variety of popular and literary magazines, shifted to health, nutrition, and consumer topics. ${ }^{16}$ By
${ }^{6}$ Daniel Pope, “His Master's Voice: James Rorty and the Critique of Advertising," Maryland Historian 19 (1988): 6. In addition to Pope's excellent account, the two other biographical sources on Rorty are Neil Gross, Richard Rorty: The Making of an American Philosopher (Chicago: University of Chicago Press, 2008), chap. 1; and John Michael Boles, “James Rorty's Social Ecology: Technology, Culture, and the Economic Base of an Environmentally Sustainable Society," Organization \& Environment 11, no. 2 (1998): 155-79.

${ }^{7}$ Gross, Richard Rorty, 36; and Pope, "His Master's Voice," 6.

${ }^{8}$ Pope, "His Master's Voice," 7; and Gross, Richard Rorty, 36.

${ }^{9}$ Raushenbush trained in Chicago's famed Sociology Department and, along with other research support, assisted Robert Park in his 1922 The Immigrant Press and Its Control (New York: Harper \& Bros.). Raushenbush, a writer in her own right, worked closely with Rorty on his prose projects, including Our Master's Voice. Late in life she published a biography of Park, Robert E. Park: Biography of a Sociologist (Durham, N.C.: Duke University Press, 1979).

${ }^{10}$ In 1927 Raushenbush and Rorty, for example, were arrested in Boston for protesting the imminent executions of Nicolo Sacco and Bartolomeo Vanzetti. Boles, "James Rorty's Social Ecology," 159.

${ }^{11}$ Rorty was a founding co-editor of the New Masses in 1926, though he was ousted the next year after political and editorial disputes. Pope, "His Master's Voice," 8; Gross, Richard Rorty, 3on4; and Alan M. Wald, The New York Intellectuals: The Rise and Decline of the Anti-Stalinist Left from the 1930 so the 1980 s (Chapel Hill: University of North Carolina Press, 1987), 54-55.

${ }^{12}$ Pope, "His Master's Voice," 8.

${ }^{13}$ Newman, Radio Active, 59-60.

${ }^{14}$ Gross, Richard Rorty, 51-52; and Boles, "James Rorty's Social Ecology," 160. For a detailed account of Rorty's early 1930s entanglements with the Communist 
the 1950 se had become an aggressive Cold Warrior, penning antiSoviet scripts for the Voice of America and clamoring for the American Communist Party's legal shuttering. ${ }^{17}$ His 1954 McCarthy and the Communists, co-authored with Moshe Decter, faulted the Wisconsin senator for botching the anticommunist cause-for discrediting the otherwise urgent campaign to purge Reds. ${ }^{18}$

Rorty wrote on a range of other topics through the early 1960s, including technology, race relations, food culture, and, notably, ecological issues - the last an area he had addressed, precociously, all the way back in the early $1930{ }^{19}{ }^{19}$ Even as Rorty drifted right, he remained a critic of the country's acquisitive culture. In an unpublished reflection—written a decade before his 1972 death—he looked back on his Depression-era critique of advertising:

I wrote Our Master's Voice with the object of curing surgically what I considered a malignant degeneration of culture: Advertising. Not only did I not cure it; the disease like a cancer increased not only relatively to the total culture but absolutely so that one might well say that the American culture is dying from this malignancy. ${ }^{20}$

\section{Systematized ILlUSIONS}

It was Thorstein Veblen, not Marx, who supplied for Rorty the book's argumentative anchor. Rorty acknowledged his debts to the splenetic economist-cum-social critic with such regularity, and with such reverence, that the book can be read-at one register-as an extension of Veblen's scattered remarks on advertising. Though Veblen treated "salesmanship" as an important constituent of the pecuniary culture, he never devoted a treatise to the business of selling. One of just two sustained meditations on advertising appeared in a late work, the 1923 Absentee Ownership, and it was this chapter (on "Manufactures and Salesmanship") that animated Rorty's analysis. ${ }^{21}$ Yet Veblen's imprint sinks deeper than that. Rorty's scabrous ironizing, for example, pays explicit homage to his onetime teacher. And the concept of emulation - the dynamic of prestige and consumption that Veblen outlined in The Theory of the Leisure Class (1899) - is the real engine of Our Master's Voice. ${ }^{22}$ Rorty notably refused to isolate selling from the wider "pseudoculture," opting instead for a fisheye-lens approach.

In that respect Our Master's Voice constitutes an enlargement, even a gentle overhaul, of Veblen's critique of advertising.

Rorty was already familiar with Veblen's work when he attended the elder scholar's classes at the New School for Social Research in the early 1920 s. $^{23}$ According to Rorty's unpublished memoirs, he and Veblen struck up a brief friendship while living in the same New York City boarding house. Rorty and the building's owner
Party, fast disillusion, and Trotskyite sympathies, see Wald, The New York Intellectuals, 56-62, 102-5, 271. A trio of prominent anti-Stalinist Marxist intellectuals-Sidney Hook, Elliot Cohen, and Meyer Schapiro-are thanked in Our Master's Voice for their help with the manuscript. $O M V$, x.

${ }^{15}$ Richard Rorty, "Trotsky and the Wild Orchids," in Philosophy and Social Hope (New York: Penguin, 1999), 6. James Rorty had nearly accompanied the philosopher John Dewey to Mexico for Dewey's investigation into the Moscow Trotsky show trials. As Richard Rorty remembers, the two-volume Dewey Commission report "were books that radiated redemptive truth and moral splendor" ("Trotsky and the Wild Orchids," 5).

${ }^{16}$ Boles, "James Rorty's Social Ecology," 162-63.

${ }^{17}$ Pope, "His Master's Voice," 14.

${ }^{18}$ James Rorty and Moshe Decter, McCarthy and the Communists (Boston: Beacon, 1954). Rorty's anti-communism soon took a paranoid turn, as Pope notes: "Rorty was convinced that the Communist Party had planted its agents as handymen on his Connecticut farm, had joined forces against him with Morris Fishbein of the American Medical Association, and had induced fellow-traveling bookstore clerks to hide his writings from public display." Pope, "His Master's Voice," 14n41. See also Wald, The New York Intellectuals, 272-73. ${ }^{19}$ Boles, "James Rorty's Social Ecology," 161

${ }^{20}$ Quoted in Pope, "His Master's Voice," 14.

${ }^{21}$ Thorstein Veblen, Absentee Ownership and Business Enterprise in Recent Times: The Case of America (New York: B. W. Huebsch, 1923), chap. 11. The other treatment, which Rorty rarely cited, appears in Veblen, The Theory of Business Enterprise (New York: Charles Scribner's Sons, 1904), 55-6o. For a superb treatment of both works in the wider context of Veblen's project, see Sidney Plotkin, "Misdirected Effort: Thorstein Veblen's Critique of Advertising," Journal of Historical Research in Marketing 6, no. 4 (2014): 501-22.

${ }^{22}$ Veblen, The Theory of the Leisure Class: An Economic Study in the Evolution of Institutions (New York: Macmillan, 1899).

${ }^{23}$ Veblen was among the New School's 
detailed to Veblen their experiences in the ad business-testimony that, Rorty later claimed, informed Veblen's analysis in Absentee Ownership. Wrote Rorty: "What he got out of us was transmuted into the refined gold of the long footnote" on religion in the book's advertising chapter. ${ }^{24}$ If Rorty was right-that Veblen's excursus on the "propagation of faith" reflected their conversations from the early 1920s-then the compliment was returned in Our Master's Voice. He singled out Veblen's "footnote"-really a six-page addendum to the chapter-as the key to grasping the resonance of Christianity and the "modern Church of Advertising." 25

Rorty dedicated Our Master's Voice to the "memory of Thorstein Veblen," and he quoted him in one of the book's three epigraphs. ${ }^{26}$ Veblenian lacerations-phrases like doctrinal memoranda and creative psychiatry_pockmark Rorty's pages. ${ }^{27}$ And sentences like "Again, Veblen furnishes us with the essential clue," are typical. ${ }^{28}$ Veblen's name appears more than three dozen times in Rorty's treatise-or once every seven pages. Thus it seems fair to conclude, at first pass, that Our Master's Voice is the book Veblen would have written had he devoted himself to the task.

Rorty certainly encouraged that inference. He lavished particular praise on Absentee Ownership. Veblen's "brief treatment of advertising" in the book, Rorty wrote, "remains today the most exact description of the nature of the advertising phenomenon which has yet appeared." 29 Late in Our Master's Voice, Rorty admitted that Veblen's volume, "in general, has supplied the framework of theory for this analysis." ${ }^{\circ}$ Readers might thus easily get the impression that Our Master's Voice offers but a book-length elaboration of Veblen's penetrating, if brief, reflections on advertising.

This isn't quite right. Rorty, for all his borrowings, departed from his teacher in a handful of significant ways. He placed advertising at the center of things where Veblen, if anything, deflated its importance. For Veblen, advertising didn't change much; its main effect was to shuffle the allotment of sales among firms all vying for a fixed, zero-sum buying capacity. Yet Rorty, writing in the wake of the Gatsby-esque 1920s, realized that advertising had helped change the economy itself, expanding (together with popular credit instruments) the role of everyday consumption. Without using the phrase, Our Master's Voice articulated the idea of demand stimulation-the adfueled fanning of consumer desire that helped remake the country's economy and culture. Rorty's reflections on the interlaced economics of publicity and consumption were, to be sure, tempered by the brute fact of the Depression. But the blueprint of an advertising-stimulated consumption economy-an answer to overproduction and slack demand-exists in Our Master's Voice. The book anticipates, more founding faculty. See Peter M. Rutkoff and William B. Scott, New School: A History of the New School for Social Research (New York: Free Press, 1986), $14-16$.

${ }^{24}$ This account of Rorty's brief personal exposure to Veblen is drawn from Boles, "James Rorty's Social Ecology," 157. Boles cites, and quotes from, Rorty, "Unpublished Memoirs: Version 1," n.d., box 2, James Rorty Papers, Special Collections, University of Oregon. Veblen's "Note" appears in Absentee Ownership, 319-25. The owner of the boarding house, Alice Boughton, was research director at the J. Walter Thompson Company. Pope, "His Master's Voice," 6-7.

${ }^{25}$ Rorty, before quoting Veblen's first paragraph, wrote: "The close analogy between the sales publicity methods of the Christian Church and those of the modern Church of Advertising was noted in 1923 by Thorstein Veblen, who missed little, if any, of the comedy of the American scene. Veblen's long foot-note (p. 319, Absentee Ownership) should be read in its entirety in this connection." $\mathrm{OMV}, 208$.

${ }^{26} \mathrm{OMV}, \mathrm{v}, 2$

${ }^{27} \mathrm{OMV}, 13,176,182,185,201,274,278$, 285

${ }^{28} \mathrm{OMV}, 152$.

${ }^{29} \mathrm{OMV}, 173$.

${ }^{30} \mathrm{OMV}, 223$. 
than Veblen's work, the fuller postwar articulation of advertising's Keynesianism-through-desire. ${ }^{31}$

Crucially, Veblen embeds his treatment of the "business of publicity" in his broader analysis of the U.S. economy. $3^{2}$ The core idea, from The Theory of Business Enterprise (1904) onward, is that businesses deliberately scale back production to protect their profits-to prevent prices from falling below costs. Veblen called this "sabotage," with profit-hoarding "business" hollowing out "industry." Since the "market is not to be overstocked to an unprofitable extent," the captains of business turn to the "strategic withholding of productive efficiency." 33 Veblen regarded the slackening as deeply offensive-an affront to the country's productive capacity and a deplorable and selfish waste, one that underwrote a parasitic leisure class.

Veblen applied this sabotage framework, including its Norwegian asceticism and producerist ethic, to advertising itself-resulting in a strikingly autarkic analysis. Spending on "salesmanship," Veblen's preferred term, was growing rapidly, leading to higher prices for consumers. Yet all those advertising outlays merely reshuffled a deck of, ultimately, capped size: "The total volume of sales at any given time is fixed within a narrow margin." Salesmanship is all about winning customers from competitors-" "the art of taking over a disproportionate share of this run of sales."34

Yes, Veblen concluded, advertising matters; after all, it's taking a growing share of the economy and running up production costs (and therefore prices). Yet he ultimately considered it waste, professionalized waste, since what's at stake is market share among big profit-protecting firms. To Veblen, the proportion of the economy given over to consumption was a zero-sum game. ${ }^{35}$ Salesmanship resembled trench warfare, with small, meaningless gains made at great expense. The whole sector, then, was irrational, if also explainable: Firms ramp up publicity spending as a competitive necessity, since otherwise their competitors will drive them out of business with their own campaigns. ${ }^{36}$ This arms race generates a sprawling, even routinized advertising industry—staffed by "publicity engineers" trained (to Veblen's disgust) at the country's most august universities. 37

Thus salesmanship, to Veblen, constituted a wasteful $\operatorname{cog}$ in a system characterized, even defined, by business sabotage. Modern capitalism was the story of business deliberately holding back the country's productive capacity. This claim served as the bedrock of Veblen's economics, and he erected his analysis of advertising on its foundation. Advertising, in fact, was just another layer of business sabotage in Veblen's terms-indeed a symptom rather than a cause. He called it "salesmanlike sabotage." 38

The closest Veblen got to conceding advertising's broader stirring
${ }^{31}$ The classic statements of publicitydriven demand stimulation vis-a-vis the wider U.S. economy are John Kenneth Galbraith, American Capitalism (New York: Houghton Mifflin, 1952), 98-102; and Galbraith, The Affluent Society (New York: Houghton Mifflin Harcourt, 1958), chap. 10. My interpretation of Veblen's economics of advertising differs from those of Sidney Plotkin, Georgios Patsiaouras, and James Fitchett, who draw a more direct line from Veblen to analyses like Galbraith's. See Plotkin, "Misdirected Effort," 502; and Georgios Patsiaouras and James A. Fitchett, "The Evolution of Conspicuous Consumption," Journal of Historical Research in Marketing 4, no. 1 (2012): 164-65.

${ }^{32}$ Veblen, Absentee Ownership, 300.

${ }^{33}$ Veblen, Absentee Ownership, 285.

${ }^{34}$ Veblen, Absentee Ownership, 287. Only in a footnote did Veblen make a qualified concession to the stimulative potential, or at least diversion from savings, of advertising — and even then there's only a "little something" at stake: "There is the qualification . . . that the current, very urgent, salespublicity may be presumed to divert a little something from savings to consumptive expenditures, and so may add that much of a margin for funds to the volume or purchasing-power currently available for expenditure on advertised goods" (309n14).

35 Veblen made the point repeatedly, without ambiguity: "The total volume of purchasing funds available at any given time [is] fixed within a relatively narrow margin of fluctuation. So that each of these competitive sellers can gain only at a corresponding loss to the rest." Veblen, Absentee Ownership, 299. Advertising operates in a "closed market," one in which "one seller's gain is another's loss" (299-300).

${ }^{36}$ The competitive inter-firm emulation-the advertising arms race-leads to "a continued increase of sell-costs and a continually more diligent application to salesmanship." 
of desire-its stimulus to an emerging consumer culture-is in passing reference to the production of customers. If salesmen make anything, he claimed, it's the buyers for their clients' products. Advertisers may write copy, design billboards, and the rest, but they're really all about the "fabrication of customers," the manufacture of consumers. 39 This is, indeed, in the territory of demand stimulationand it's a claim, however fleeting, that Rorty ran with in Our Master's Voice. Veblen himself pulled back from the full implications of the production of desire, on the same autarkic grounds that animate his wider analysis. "There is, of course, no actual fabrications of persons endowed with purchasing-power ad hoc"-even if ad agencies liked to claim otherwise. The reason? The economy is a closed system, with a fixed customer base. "Viewed in the large, what actually is effected is only a diversion of customers from one to an other of the competing sellers, of course." 40 So salesmen manufacture customers, but only within the economy's existing enclosure.

Rorty's claims notwithstanding, the debts that Our Master's Voice owes to Veblen are more protean. There is the cutting moralism itself. Salesmanship, to both men, was tragic and farcical-the practice (in Veblen's words) of getting "a margin of something for nothing, and the wider the margin the more perfect the salesman's work." 41 Rorty adopted Veblen's caustic comedy as his own prose style too. Phrases like the "blandishments of the huckstering salesman" could appear in the paragraphs of either writer. ${ }^{42}$ A handful of the Veblenian witticisms indeed appear repeatedly in Our Master's Voice, and these mark the real register of the senior scholar's influence. Such arguments-in-a-phrase, moreover, are often rescued from Veblen's footnotes-mined and polished by Rorty, then expanded into chapter-length meditations.

Consider a single, high-density footnote in Absentee Ownership:

The production of customers by sales-publicity is evidently the same thing as a production of systematised illusions organized into serviceable 'action patterns' - serviceable, that is, for the use of the seller on whose account and for whose profit the customer is being produced. It follows therefore that the technicians in charge of this work, as also the skilled personnel of the working-force, are by way of being experts and experimenters in applied psychology, with a workmanlike bent in the direction of what may be called creative psychiatry. Their day's work will necessarily run on the creative guidance of habits and bias, by recourse to shock effects, tropismatic reactions, animal orientation, forced movements, fixation of ideas, verbal intoxication. It is a trading on that range of human infirmities which blossom in devout observances and bear fruit in the psychopathic wards. 43

Our Master's Voice, to a remarkable extent, offers a four hundredpage meditation on this single passage from the small-type depths
Veblen, Absentee Ownership, 288. Advertising, once one company starts spending, imposes a "necessity to all the rest, on pain of extinction." The result is a "competitive multiplication" of the "ways and means of salesmanship"; firms have no choice but to ramp up their expenditures as a defensive maneuver, on "penalty of failure" (303-4).

37 Veblen, Absentee Ownership, 296. Veblen devoted an acidic, footnoted paragraph to the emergence of business, marketing, and advertising degree programs. Universities, he wrote, are "turning out a rapidly swelling volume of graduates in this art of 'putting it over.' " This "scholastic propagation of salesmen" is both a contributor to, and a reflection of, the ad profession's formalization-its "standardised" processes and output (306n12).

$3^{8}$ Veblen, Absentee Ownership, 296.

39 Veblen, Absentee Ownership, 306. Veblen: "Judicious and continued expenditures on publicity and the like expedients of salesmanship will result in what may fairly be called a quantity-production of customers for the purchase of goods or services in question" (305).

$4^{40}$ Veblen, Absentee Ownership, 305n11.

${ }^{41}$ Veblen, Absentee Ownership, 291. Veblen contrasted salesmanship with "workmanship" as "two habits of thought" — the latter defined as the "old order of industry, under the regime of husbandry, handicraft and neighborhood workmanship." Publicity and the art of the sale are gaining on workmanship, which however survives as a "slow-dying prejudice" in pockets of the culture (291-92).

${ }^{42}$ Veblen, Absentee Ownership, 290.

${ }^{43}$ Veblen, Absentee Ownership, 3067 n12. The footnote's first paragraph, on the uptake of advertising in higher education, is not quoted here. 
of Veblen's tome. The paired-word phrases-systematized illusions, action patterns, and creative psychiatry - for Rorty supplied the key insight. He invoked the terms, quoted them with reverence, and then unspooled them with a sustained concentration that exceeded (or delivered on) Veblen's fleeting mentions. Even the footnote's last sentence, with its "human infirmities" and "psychopathic wards," registers in an outsized manner in Our Master's Voice, featured as one of the book's three epigraphs. 44

Veblen's footnote, and the other bits of Absentee Ownership that drew Rorty's attention, center on the psychology of advertising's appeal. The business of publicity, in Veblen's phrase, is "applied psychology," the calculated exploitation of human irrationality. Veblen's treatment of the theme remained, again, brief: This footnote and two additional, probing pages. 45 The advertiser's "raw material," to Veblen, was "human credulity," his product, "profitable fixed ideas." The main strategy preyed on fear in general, and on fear of losing prestige in particular. ${ }^{6}$ The prospect of embarrassment, the shame at falling behind one's peers, marks the target of the ad-man's "intoxicating verbiage." 47

Here Veblen had re-entered the territory of his earlier and most famous work on competitive emulation, The Theory of the Leisure Class (1899). It's this Veblen that animates Rorty's book, more than the later works' economics of business sabotage. To Rorty, advertising's fundamental mechanism exploited the emulative yearnings of consumers. Publicity, indeed, serves as the main prop to a wholesale culture of acquisitive emulation-in the thick, pervasive sense of "culture." For Rorty, more than for his teacher, advertising cut deep.

He was quick, for example, to grant some autonomy to advertisers themselves-to their aesthetic pretensions and professional self-regard. As "advertising craftsman," we (Rorty included himself) are motivated not just by money but also by "an obsessed delight in the materials of our craft." Thus business may indeed sabotage industry in the broad sense. "True," Rorty wrote. But as creative workers, "we were and are parasites and unconscious saboteurs too." The ad-man's artistic self-image comes in for relentless mockery, but at the same time Rorty carved out a certain space-and considerable sympathy-for his peers in the ranks of copywriters and graphic artists. He even went so far as to suggest that capitalism's "exploitative functionaries," in their craft-driven sabotage, may yet bring the system down from within. ${ }^{8}$ This, at least, is the implication of the book's first-page encomium to Veblen:
${ }^{44}$ Rorty's quoted version, "A trading on that range of human infirmities that blossoms in devout observances and bears fruit in the psychopathic wards," is slightly different. $O M V, 2$.

45 Veblen, Absentee Ownership, 310-11.

${ }^{46}$ Veblen, Absentee Ownership, 310.

${ }^{47}$ Veblen, Absentee Ownership, $311 n 17$.

${ }^{48} O M V, 153$. See also $O M V, 242-43$. 
Dedicated to the memory of Thorstein Veblen, and to those technicians of the word whose 'conscientious withdrawal of efficiency' may yet accomplish that burial of the ad-man's pseudoculture which this book contemplates with equanimity.

The quoted phrase, the "conscientious withdrawal of efficiency," had been invoked by the Industrial Workers of the World (IWW), a radical union, as a tactic of sabotage. Beginning in 1922, Veblen had repurposed the expression as an arch shorthand for his theory of business sabotage. ${ }^{49}$ And so it appears fitting that Rorty restored the phrase's IWW meaning in the book's dedication, calling on his fellow ad workers ("technicians of the word") to sabotage their own cultural machinery.

The broader point: Rorty took advertising far more seriously than his teacher. He conceded to Veblen that salesmanship constituted a form of "economic parasitism." $5^{0}$ But for Rorty, the institution of publicity extended far beyond the economy, to the "culture considered as a system of values and motivations by which people live." 51 Thus when he brushed up against Veblen's portrait of advertisingas a closed system of allocative waste-Rorty gently pushed back. He noted that in the early 1920s, when Veblen was writing, the salesman was still an "upstart and a parvenu" - a mere cog in the businessman's self-sabotaging gear-works. "But times have changed," Rorty insisted. Advertising had since become an industry "no less essential than coal or steel." It was now no longer merely an appendage to business: in the decade since Absentee Ownership, the ad-man had become the "first lieutenant of the new Caesars of America's commercial imperium not merely on the economic front but also on the cultural front." 52 By culture Rorty meant the whole American belief system, one increasingly fixed on status competition-on emulation and one-upmanship, fueled by advertising's appeal to human infirmity.

\section{The TheORY OF THE LeIsURe ECONOMY}

Our Master's Voice was published at the Depression's nadir, so it's surprising that Rorty focused his attention elsewhere. The book does occasionally nod to the economy's free fall, often in service to the claim that capitalism would soon collapse. There are other moments of note, including five phantasmagoric pages on advertising as a giant machine- $\mathrm{a}$ "coldly whirring turbine" that emits life-draining "jabberwocky," even as its human fuel runs down in the Depression's fourth punishing year. ${ }^{53}$ But to a remarkable extent, the book remains focused on the fulsome 1920 and the decade's "endless chain of selling." 54 The Depression itself comes off as a late-arriving
${ }^{49}$ See Veblen, Engineers and the Price System (New York: B. W. Huebsch, 1921), 1, 8-23, 166; and Veblen, Absentee Ownership, 217-21, 285-86, 394-403.

${ }^{50}$ See, for example, Rorty: "In the Theory of Business Enterprise and elsewhere in the whole body of his work, Veblen notes that advertising is one element of the 'conscientious sabotage' by which business keeps the endlessly procreative force of science-in-industry from breaking the chains of the profit system."

$O M V, 152-53$. See also $54-55$.

${ }^{51} \mathrm{OMV}, 79$.
${ }^{2} \mathrm{OMV}, 233-34$. Even Veblen's meditation on the twinned propagandas of religion and advertising-a point that Rorty, apparently, had helped inform in the course of the two men's brief friendship in the early 1920s-struck Rorty, by the 1930s, as obsolete. Veblen's "ironic patronage of the emerging priesthood of advertising," Rorty wrote, "sounds astonishingly inept and dated." Religion proper had lost its hold since Veblen's book, while the "religion of the ad-man is everywhere dominant both as to prestige and in the matter of administrative control" (209).

${ }^{53}$ Wrote Rorty: “After four depression years the jabberwocky is hungry. It has devoured large sections of the lower and lower middle classes and expelled 
character, granted a few short lines. The spotlight, instead, shines on advertising's success-via emulation and "style-terror"—at manufacturing new desire. 55

Rorty claimed that the economy, weighed down by surplus production, required an artificial stimulus of demand. The problem, in the "'surplus economy' phase of industrial capitalism," is overproduction..$^{6}$ The solution is advertising. On this point Rorty was blunt and repetitive: The engine of the economy needs the "ad-man's foot on the throttle, speeding up consumption, preaching emulative expenditure, 'styling' clothes, kitchens, automobiles-everything in the interest of more rapid obsolescence and replacement." 57 The economist's account of supply and demand in natural harmony, in self-regulating equilibrium, was itself obsolete. The crucial function of publicity, then, was to rescue capitalism - to animate, or even to create whole cloth, customers to consume the system's excess capacity. Any lingering "puritanism in consumption" in the populace proved "intolerable," and had to be snuffed out. ${ }^{8}$ Here is Rorty's key departure from Veblen: Where the teacher saw deliberate slackening of supply - sabotage-the pupil saw ventilation of demand.

This was advertising's indispensable role, and it served as the basis for Rorty's otherwise startling claim that newspapers, magazines, radio, and the cinema were, at their core, "advertising media." 59 All the column-inches of newsprint, the radio dramas, the latest Hollywood releases amounted to "filler," intended merely to entice readers or moviegoers to consume the ads. ${ }^{60}$ If the commercial media had an overriding objective, it was to "nourish and stimulate the buying motive." ${ }^{\prime 1}$ The point of the media's editorial or narrative trappings, in other words, was to package and deliver audiences to advertisers. ${ }^{62}$ It makes for a striking argument, partly because it anticipates, by a half century, the claims of scholars like Sut Jhally and Dallas Smythe that the "audience commodity" constitutes the real product of commercial mass media. ${ }^{63}$

For Rorty, the mechanism for making buyers out of citizens came in the form of induced emulation. In the spirit of Veblen's Theory of the Leisure Class, advertising preyed on the anxieties of comparative social worth to spur consumption. If advertising at core was the "competitive manufacture of consumption habits," its technique (in Rorty's favorite Veblenism) was "creative psychiatry." 64 The populace is driven to buy so as to forestall social slippage: this is the governing logic of a consuming culture fanned by the agencies and the media businesses they underwrite. "Advertising," Rorty wrote, in one of many equally vigorous summations, "is a doctrine of material emulation, keeping up with the Joneses, conspicuous waste." 65 Rorty's shorthand for all this, the ad-man's "pseudoculture," is also their dry bones, burned clean of their buying power, into the out darkness. There the electric breath of the jabberwocky still plays on them, but they are ash and slag. They cannot burn, they cannot feed the machine" $(O M V, 54)$.

$54 O M V, 31$.

${ }^{55} \mathrm{OMV}, 157$.

${ }^{56} \mathrm{OMV}, 211$.

${ }^{57} \mathrm{OMV}, 8-9$

${ }^{58} \mathrm{OMV}, 176$.

${ }^{59} \mathrm{OMV}, 115$.

${ }^{60} \mathrm{OMV}$, 66. "To the magazine editor and the ad-man the magazine consists of two parts: advertisement and filler," wrote Rory. "The filler is designed to carry the advertisements. With rare exceptions, no way has so far been discovered of getting the public to pay for advertisements presented without filler. Hence the filler."

${ }^{61} \mathrm{OMV}, 56$.

${ }^{62} \mathrm{OMV}, 115$.

${ }^{63}$ See Dallas W. Smythe, Dependency Road: Communications, Capitalism, Consciousness, and Canada (Norwood, NJ: Ablex, 1981); and Sut Jhally, "Probing the Blindspot: The Audience Commodity," Canadian Journal of Political and Social Theory 6, no. 1-2 (1982): 204-10. ${ }^{64} \mathrm{OMV}, 274$.

${ }^{65} \mathrm{OMV}$, 14. See also $O M V, 24,56-57$, 157-58, 179, 196, 211, and 224. 
the book's key term, its indictment by neologism.

Ironically to Rorty, advertisers turned to an older, "organic" culture for their source material, one they were at the same time busily dislodging. ${ }^{66}$ In other words, the acquisitive social psychology demanded by the economy fed off the country's past-its pastoral humanism and small-town craftsmanship, creating a parasitic relationship between advertising and the country's organic culture. Yet problematically for advertisers, the pseudoculture held only a shallow appeal, since the population "wistfully desire[d]" the "older more human culture."67 As a result, the editorial recipe for the advertisingdependent media needed-if it wanted Americans to watch, read, and listen-to include ingredients from the country's half-displaced organic past.

Rorty develops the argument in the book's remarkable sixth chapter, a sprawling, chart-filled report on a study of thirteen masscirculation magazines that, by the author's own account, was "almost wholly" the work of his wife, Winifred Raushenbush, and a colleague. ${ }^{68}$ The chapter offers a self-contained, empirically rich treatment of the country's stratified magazine market, one tailored to specific "class cultures." 69 Only those titles targeting the wealthy, like Harper's Bazaar, bathed readers in undiluted snobbism. In the restthose outlets aimed at the poor and the middle class-the acquisitive culture "battles" with an "older tradition and culture." Many titles leaned emulative, in other words, while the remainder favored the "organic." Either way, they presented a "considerable admixture" of the new and old-and by necessity. "One may say, in summary, that the acquisitive culture cannot stand on its own feet," the authors wrote; "it does not satisfy."70 Hence the need for parasitism.

Rorty and his coauthors found a measure of hope in the population's implicit rejection of raw emulation: "The American people do not like this pseudoculture, cannot live by it, and, indeed, never have lived by it." Here and elsewhere in the book, a residue of romantic nostalgia emerges, a plaintive register of displacement-despite the work's many professions of forward-facing radicalism. ${ }^{71}$ For example, the authors claim that the Depression-ravaged country yearns to "discover by what virtues, by what pattern of life, the Americans of earlier days succeeded in being admirable people, and in sustaining a life, which, if it did not have ease and luxury, did seem to have dignity and charm." If that sounds like an endorsement, the Rorty and his colleagues quickly pivoted to more radical prospects. Yes, the organic past was the population's "main drift of desire," but "other drifts" existed too: "Some editors and readers even envision revolution" - a substitution of a "new culture" for the organic and acquisitive alternatives. ${ }^{72}$ This last point, however, is delivered in haste.
${ }^{66}$ Wrote Rorty, for example: "The advertising-manufactured substitute for these organic cultures is a national, standardized, more or less automatic mechanism, galvanized chiefly by pecuniary motivations and applying emulative pressures to all classes of the population." $O M V$, 50. In a prescient aside on the rise of the advertisingmocking magazine Balyhoo in the early 1930s, Rorty observed how easily advertisers adapted to its fang-less satire. Balyhoo is an enterprise in "tertiary parasitism": advertising is a parasite on business, and the magazine, in turn, "parasites on the grotesque, bloated body of advertising" (278).

${ }^{67} \mathrm{OMV}$, 57. Interestingly, Rorty identified sexual frankness with the older organic culture (6o, 79-80). In the "field of sex," the "mature artist exhibits neither timidity nor shame," he wrote, citing D. H. Lawrence and Walt Whitman (the latter of whom Rorty's poetry was often compared). The "commercial sex fictioneer," by contrast, must make his prudish surrender to "Puritan conviction" (87-88). There is an unmistakeable Freudian undercurrent to the book's treatment of sex, which seems unsurprising given Rorty's intellectual milieu. As he wrote in the chapter devoted to the theme, "The enterprise of turning people, with their normal sexual desires and human affections, into gold, is greatly helped by the fact that our Puritan cultural heritage is peculiarly rich in the psychopathology of sex" (162, chap. 12). Rorty's aversion to the "residual Puritanism" informed his extended, and vituperative, dismissal of the early 1930s Payne Fund studies of movies and children (188-94). "Although the investigators made much pother about the 'objective' 'scientific' nature of this fact-finding study, they could scarcely escape value judgments, and Mr. Forman [in the summary volume] frankly applies such judgments in his popularization. They are middleclass value judgments, derived from the conventional mores of the middle-class community, and applied to an industry which is organized to serve not the classes, but the masses" (192-93). The Payne Fund actually asked Rorty to review the studies' popular summary 
It appears limp and convictionless-a forced incantation of radical faith that the book's authors, in the end, seem to doubt.

\section{It Could Happen Here}

The ad-man's pseudoculture resembles a living thing, but it is, to Rorty, devoid of all life-inorganic and artificial. His prose turns purple on this point. The pseudoculture

is a robot contraption, strung together with the tinsel of material emulation, galvanized with fear, and perfumed with fake sex. It exhibits a definite glandular imbalance, being hyperthyroid as to snobbism, but with a deficiency of sex, economics, politics, religion, science, art and sentiment. It is ugly, nobody loves it, and nobody really wants it except the business men who make money out of it. It has a low brow, a long emulative nose, thin, bloodless, asexual lips, and the receding chin of the will-less, day-dreaming fantast. The stomach is distended either by the abnormal things-obsessed appetite of the middle-class and the rich, or by the starved flatulence of the poor. Finally it is visibly dying for lack of blood and brains. 73

It's the last line's claim-that the publicity regime would soon collapse under its own diseased weight-that Rorty had trouble sustaining in the balance of the book. In Rorty's holistic terms, the demise of advertising amounted to the end of capitalism, as the two share a fate. The publicity industry may be an effect of, an emanation from, the market economy, but it remained indispensable all the same. Behind the ad-man lay the "whole pressure of the capitalist organism," Rorty proclaimed, "which must sell or perish."74

So the question of when, or whether, advertising and its enfolding economy would, in fact, perish haunts Our Master's Voice. One thread in the book seems hopeful: The system is edging, inevitably and soon, over the cliffs of history. American capitalism cannot maintain itself for long, because its "underlying economic and social premises are obsolete in the modern world."75 So too with advertising: "One needs but little knowledge of history, or of the movement of contemporary economic and social forces, to know that it can't last." Its tower, Rorty added, is tottering. ${ }^{6}$

Is it possible to rehabilitate the ad-man's pseudoculture? The answer, to Rorty, is the "same answer which must be given to the question: 'Is it possible to rehabilitate the capitalist economy?' " No. Both the economy and its acquisitive culture are caught in late-stage decadence- "very frail and ephemeral," primed for revolutionary toppling. And so, in this thread of the book, Rorty dismissed efforts at reform, relentlessly pummeling liberal social critics, some of them social scientists. Their carefully targeted interventions-their calls volume before its publication; Rorty excoriated the book so savagely that the Fund considered stopping publication. See Garth Jowett, Ian C. Jarvie, and Kathryn H. Fuller, Children and the Movies: Media Influence and the Payne Fund Controversy (Cambridge: Cambridge University Press, 1996), 107-8. ${ }^{68} \mathrm{OMV}$, x. The chapter's third author is named as Hal Swanson, without further identification.

69 "The United States," the authors wrote, "does not have one homogenous culture; it has class cultures" (OMV, $60)$.

$7^{70} \mathrm{OMV}, 61$.

${ }^{71}$ In his memoir the philosopher Sidney Hook captured some of his friend's yearning for an authentic past, including its ecological dimension: "James Rorty was at heart a poet, sickened by the commercialism of capitalist life and culture and up in arms at the cruelties and injustices of the depression. He made his political choices on the basis of his moral empathy and his sense for the integrity and authenticity of the persons with whom he associated. He had a love for the soil and the natural life, and long before the environmental movement was born, he held forth against the evils of pollution and the dangers of the use of chemicals and preservatives in the nation's food supply." Hook, Out of Step: An Unquiet Life in the 2oth Century (New York: Harper \& Row, 1987), 182. As Daniel Pope observes, Rorty's putative Marxism coexisted with a longingshared by many other Depression-era intellectuals-for "community and authenticity in a fragmented and baffling society." Pope, "His Master's Voice," 10. ${ }^{72} \mathrm{OMV}, 79$.

${ }^{73} \mathrm{OMV}, 85$.

${ }^{74} \mathrm{OMV}, 34$.

${ }^{75} \mathrm{OMV}$, 9. For an interesting discussion of Rorty's perch between hope and disillusion, see Dan Schiller, Theorizing Communication: A History (New York: Oxford University Press, 1996), 69-71.

${ }^{76} \mathrm{OMV}, 25$. 
for ethics and standards in the profession, for example-appear like the snake oil ads they aim to eradicate. The competitive pressures of advertising required mendacity; codes and reforms, "under our existing institutional setup," would either deprive stockholders or inflate consumer costs. The alternative to bad advertising wasn't good advertising; it was "no advertising."77

To Rorty, the effort to isolate the trade from its economic enclosure, then to rub away its most appalling stains, constitutes an act of self-congratulatory futility. He deemed criticism of advertising's corruption of journalism, for example, "beside the point," since its roots sank so deep: "the objective forces of the competitive capitalist economy." ${ }^{8}$ Likewise, draft New Deal legislation to stymie the publicity industry's most egregious charlatans would leave the machinery of advertising whirring: "Congress can and probably will legislate itself blue in the face, without changing an iota of the basic economic and cultural determinants."79 The industry's mendacity could not be burned off; it proved elemental, impervious to the starchy meliorism of liberal do-gooders.

Rorty took the anti-reformist position to its logical conclusion, refusing the commonplace distinction between propaganda and education. For post-World War I critics of propaganda, education stood as the salutary other-an antidote to manipulation and inoculation in the classroom. ${ }^{80}$ Rorty would have none of that. He lumped in schools and universities with the most shameless propaganda factories: the "purpose and effect of these combined institutions" was "rule"-by which he meant "their shaping and control of the economic, social and psychological patterns of the population in the interests of a profit-motivated dominant class, the business class." 81 To Rorty, the defenders of education themselves engaged in acts of propaganda, in contrast to the advertising man, who was at least unblinkered about his art's pervasive reach. ${ }^{82}$ In their way, schools and colleges proved more insidious than the overt persuasion industries, since educators cloaked their fealty to the "interest and prejudices of the ruling class." 83 At any rate, Rorty saw nothing redemptive about schooling in a capitalist order:

Advertising is propaganda, advertising is education, propaganda is advertising, education is propaganda, educational institutions use and are used by advertising and propaganda. Shuffle the terms any way you like ... all three, each in itself, or in combination, are instruments of rule. ${ }^{84}$

The reformist road to social change, for Rorty, equaled an accommodationist dead end. Reporters' codes of ethics and truth-inadvertising regulations made things worse by applying a patina of legitimacy to a corrupt order. That position, of course, presumed
$77 \mathrm{OMV}, 12$.

${ }^{78} \mathrm{OMV}, 115$.

${ }^{79} \mathrm{OMV}$, 139. The book's last three chapters (23-25), before the brief conclusion, offer a meticulously detailed chronicle of then-pending advertising legislation. For a history of these debates, and their complicated denouement, see Inger L. Stole, Advertising on Trial: Consumer Activism and Corporate Public Relations in the 1930 (Champaign: University of Illinois Press, 2006), chap. 3. Though Rorty repeated his arguments against reform-downplaying the legislation's merits and even the nascent consumer movement behind the push-he also, half-grudgingly, admitted that the laws were worth passing anyway. Even the most robust bill would "still leave untouched the major contradictions of capitalism." The fight is "none the less important and fruitful," in part because the agitation itself has "brought to light serious cleavages between the vested interests affected" $(O M V, 283)$.

${ }^{80}$ On propaganda critics and education in the interwar years, see J. Michael Sproule, Propaganda and Democracy: The American Experience of Media and Mass Persuasion (New York: Cambridge University Press, 1997).

${ }^{81}$ OMV , 114.

${ }^{82}$ Rorty took sustained aim at the sociologist Frederick Lumley and his recently published The Propaganda Menace (New York: The Century Co., 1933). Lumley hinged his critique on the education/propaganda contrast, Rorty noted. "And it is precisely there that his definition falls down" (OMV, 116). Rorty was especially irritated by Lumley's apparent indifference to the 
that revolution was possible, even likely. And in his dismissal of evolutionary, stepwise change, Rorty-no doubt knowingly-joined a debate among Marxists as old as the movement itself. If the system's collapse is imminent, and guaranteed by its own contradictions, aren't reformist palliatives just delaying the desired inevitable? It's a view fueled by the confidence that the revolution is coming-with good results.

A second strand of Our Master's Voice, sometimes awkwardly juxtaposed to the first, questions both postulates. Much of the book's thrust suggests the resilience of American capitalism-and that the system's staying power is grounded, to a large extent, in advertising itself. That's the premise of the volume's title. The ad-man's systematized illusions and creative psychiatry are what saves an exploitative system from those it exploits. This ideological role proves no less important than its economic priming: advertising is the "shaping of the economic, social, moral and ethical patterns of the community into serviceable conformity with the profit-making interests." 85 This is nothing less than "American rule-by-advertising." ${ }^{86}$ By promoting a culture of acquisitive emulation, the New York firms proffer a service to the "real rulers" in business and finance. ${ }^{87}$ They, and the media they underwrite, are the master's voice:

The point of view adhered to in this book is that of regarding the instruments of social communication as instruments of rule, of government. In this view the people who control and manage our daily and periodical press, radio, etc., become a sort of administrative bureaucracy acting in behalf of the vested interests of business. ${ }^{88}$

Here Rorty tapped into another, more pessimistic current in Marxist thought. Forced to confront the thwarted European revolutions after World War I-and anomalous success in Russia-a number of Marxist intellectuals sought to explain capitalism's durability. Theirs was the problem of consent: Why do the working classes accept, even tighten, their own chains? Figures like Antonio Gramsci and Georg Lukács, in a tradition often labeled "Western" Marxism, tended to respond that the masses took on the system's values and internalized its principles as common sense. ${ }^{89}$ Many such accounts view organs of mass communication as the principal means of cultural reinforcement. Our Master's Voice is an installment in that Western Marxist project, seeking to explain-like the others-why the revolution is always deferred.

There's a third, and final, thread in the book, an unholy mix of the first two: fear that radical social change, all too imminent, will bring fascism rather than socialism. The Weimar collapse, and the sudden visibility of homegrown fascists, weighs on the manuscript, tempering its optimism. Casual references to the average American's underlying economics, which "is itself a kind of propaganda" (117).

$83 \mathrm{OMV}, 118$.

$84 O M V, 125$.
${ }^{85} \mathrm{OMV}, 13$.

${ }^{86} \mathrm{OMV}, 16$.

${ }^{87} \mathrm{OMV}, 19$.

${ }^{88} \mathrm{OMV}, 107$.

\footnotetext{
${ }^{89}$ The best overview of Western Marxism remains Martin Jay's magisterial Marxism and Totality: The Adventures of a Concept from Lukács to Habermas (Berkeley: University of California Press, 1984).
} 
susceptibility to demagoguery appear with surprising, and discordant, frequency. In the magazine chapter, the authors observed that "it is clear that the typical American Magazine reader would go fascist." Whether another magazine's readers would "go fascist or communist" remained, they added, an open question..$^{90}$ The chapter's conclusion announces that the "democratic dogma is dying if not already dead." The poor are "oriented toward crime, and potentially at least toward revolution," while the middle classes are "oriented toward fascism." ${ }^{11}$ The book elsewhere deploys "Italy" and "Germany" (and "Russia" too) as shorthand for the possible American future. $9^{2}$

Even before the publication of Our Master's Voice, Rorty had set out on a seven-month road trip around the United States, writing magazine dispatches and a chronicle of his trip. Appearing in 1936 as Where Life Is Better, this second volume registered Rorty's dissipating confidence in the country's workers-their failure to recognize capitalism's fundamental flaws. ${ }^{93}$ He fretted about Americans' likely embrace of fascism instead-a theme foreshadowed in the haunting conclusion to Our Master's Voice, whose last page recounts a conversation with a "very eminent advertising man." He was, as Rorty realized with a "sudden chill," praising the new Nazi regime. "I venture to predict," Rorty wrote in the book's closing sentence, "that when a formidable Fascist movement develops in America, the ad-man will be right up front; that the American version of Minister of Propaganda and Enlightenment Goebels [sic] . . . will be both numerous and powerful." 94

\section{A MAster's Voice}

Despite its unrepentant leftism and fretting over fascism, Our Master's Voice received good press. Newspaper and magazine reviews were generally positive, and occasionally rhapsodic. By telling contrast, academics ignored the book. Not a single review appeared in any social science journal, and the first citation to the book, in the journal literature at least, came fourteen years later, in a law review article published in the late $1940 \mathrm{OS} .{ }^{95}$ A thorough but non-exhaustive search of 1930 scholarly books on media uncovered a smattering of references. Rorty's tome did warrant a listing in a 1935 bibliographic project by the political scientist Harold Lasswell, Propaganda and Promotional Activities. Yet Our Master's Voice, one among hundreds of references, was annotated with a single line: "Criticism of advertising as a handmaiden of American 'pseudo-culture.' "96 Only a handful of additional mentions occurred in the book literature, some dismissive and none of them substantial. 97
${ }^{90} \mathrm{OMV}, 95,96$.

${ }^{91} \mathrm{OMV}$, 98-99.

${ }^{92} \mathrm{OMV}$, 98-99.

\begin{abstract}
${ }^{93}$ James Rorty, Where Life Is Better: An Unsentimental American Journey (New York: Reynal \& Hitchcock, 1936). In keeping with Our Master's Voice, Rorty blamed the media industry: "Hollywood specializes in the manufacture of the soothing, narcotic dreams of love," while "in New York, NBC and Columbia [CBS] specialize in the manufacture of cheerio radio optimism, pre-barbaric dance rhythms, and commodity fetishism intoned by unctuous announcers" (107, quoted in Gross, Richard Rorty, 48; see also 47-50). ${ }_{94} \mathrm{OMV}, 286$.
\end{abstract}

\author{
${ }^{95}$ Ralph S. Brown, “Advertising and \\ the Public Interest: Legal Protection of \\ Trade Symbols," Yale Law Journal 57, no. \\ 7 (1948): 1167. The reference appears \\ in a footnote listing advertising's \\ "detractors": "Noteworthy among \\ general attacks on the institution was \\ Rorty, Our Master's Voice (1934)." \\ ${ }^{96}$ Harold D. Lasswell, Ralph D. Casey, \\ and Bruce Lannes Smith, Propaganda \\ and Promotional Activities: An Annotated \\ Bibliography (Minneapolis: University of
}


The popular and literary press proved far more attentive. The New York Times granted the book a full-page review, including a respectful summary registering Veblen's influence alongside Rorty's indictment of the media industry at large. ${ }^{8}$ North American Review, a literary magazine, called Our Master's Voice a "fiery discussion of the advertising racket" — "superb" on the "debunking," but hobbled by the author's revolutionary politics. ${ }^{99}$ The New Yorker described the book as a "vigorous, athletic, witty, and in parts profound analysis of and attack upon the advertising game in its broadest aspect. . . . Highly recommended."100 Syndicated treatments in the country's newspapers were at least grudgingly favorable. Rorty "takes advertising for a good humored but rather rough ride," read one. Another noted Rorty's "Socialist tendencies," but admitted that the "author has worked hard with his material" and praised the book's "mass of facts." A third syndicated review, after a taut summary, concluded:

If all that sounds like quite a mouthful, you will find it worth your while to read Mr. Rorty's book . . . all in all, this is a serious and instructive book. Some advertising men will denounce it; others, I suspect, will welcome it. And the general reader will find it exceedingly informative. ${ }^{101}$

The popular reviews-some of them flattering, none dismissiveproffer ironic testimony, perhaps, to the limits of Rorty's monovocal theory of the press. Regardless, they stand in striking counterpose to the silence from academics, then and since.

In retrospect, it's not hard to explain media scholars' neglect of Our Master's Voice - and its subsequent disappearance from the field's collective memory. After all, they ignored Rorty's fusillade in its own time. The book's peculiar form weighed it down from the beginning - its manic eclecticism and rhetorical overspillage, page by relentless page. There was, too, its author's radicalism, out of step (unblushingly so) with the performance of detachment demanded by the reigning academic norms. ${ }^{102}$ Reformist commitments, when tempered by professions of value freedom, were permissible-but not the Marx-quoting pyrotechnics of the book's prose. Rorty's status as a journalist created its own reception liability, made worse by the itinerant, topically promiscuous, fiction-tainted character of his other work. Since the 1920s, American social scientists had been avidly professionalizing, and the campaign had only gathered momentum. So mere journalism, or, worse still, social criticism, was primed for spurning by scholars who had only just won a fragile legitimacy.

And of course we shouldn't neglect the book's venom-tipped attack on social science itself. In the spirit of Veblen's 1918 polemic The Higher Learning, Rorty castigated social scientists for abdicating their assigned role as free-thinking analysts. ${ }^{103} \mathrm{He}$ lit into the "dozens of
Minnesota Press, 1935), 136. The book was dropped in Lasswell's 1946 sequel, Propaganda, Communication, and Public Opinion, a reflection, perhaps, of the twin volumes' unblushing fixation on successful propaganda. Bruce Lannes Smith, Harold D. Lasswell, and Ralph D. Casey, Propaganda, Communication, and Public Opinion: A Comprehensive Reference Guide (Princeton, N.J.: Princeton Univeristy Press, 1946).

97 The sociologist Alfred McClung Lee, for example, included the book in a listing of "recent attacks on advertised products and advertising." Lee, The Daily Newspaper in America (New York: Macmillan, 1937), 332. Likewise, the journalism scholar Robert Desmond footnoted Our Master's Voice among four other critical books in support of the statement that newspaper "owners take every step to protect their investments and, while this is natural, the public often suffers." Desmond, The Press and World Affairs (New York: D. Appleton-Century Co., 1937), 374. Hadley Cantril and Gordon Allport's The Psychology of Radio (New York: Harper \& Bros., 1935), perhaps the decade's most celebrated book-length academic treatment of media, buries Rorty's book in a footnote on censorship. They do briefly summarize Rorty's radio-oriented pamphlet Order on the Air (1934), but only to solicit and republish in full a two-page rebuttal from the National Association of Broadcasters-"since the impartial observer must learn the other side of the story" $(46,57-59)$. The final mention appears in the sociologist William Albig's Public Opinion (New York: McGraw-Hill, 1939). Citing the journalist Stuart Chase alongside Our Master's Voice, Albig wrote that a "number of intellectuals, evidencing that they felt the appeals and wiles of the advertising man to be a personal insult, have indicated their revulsion in no uncertain terms"--before mounting a qualified defense of the industry (306-9).

${ }_{98}^{8}$ The review, by the Times star reviewer R. L. Duffus, recommends the "suggestive" book, but faults Rorty for exaggerating the press's fealty to advertisers. The review carries the subhead: "There Is Truth in His Picture, but What He Shows Is by No Means the Whole Picture." Duffus, "Mr Rorty's Biased View of Modern Advertising," New York Times, May 20, 1934, 4, 14. 
Greek-porticoed" business schools, staffed by a "new priesthood of 'business economists'" who translated the "techniques of mass prevarication into suitable academic euphemisms."104 The whole discipline of economics, meanwhile, "stood aside" while advertising proceeded to "play jackstraws" with "orthodox economic doctrine."105 Rorty in fact devoted an entire chapter to psychology's prostitution to advertising, citing the for-profit Psychological Corporation and behaviorist John B. Watson's move to a big-time ad agency. ${ }^{106}$ The "prestige of business dominates the American psychology," Rorty wrote, "not excepting the psychology of American psychologists."107 And all the disciplines come in for repeated reprimand for claiming objectivity while propping up the status quo. ${ }^{108}$

Given the upbraiding, social scientists had plenty of reason to look away. ${ }^{109}$ The result, though, was the premature burial of a trenchant volume. In re-publication, Our Master's Voice joins a well-established literature on consumer culture, some of it critical—though nothing as vigorous, athletic, and witty as Rorty's forgotten study. A book about advertising, he reminded us, is inevitably a critique of the surrounding society. His example is worth emulating.
99 "[I]f communism came," continued the reviewer, "we should have all our advertising and publicity agencies turning out propaganda for the Reds, and it wouldn't be a bit more fundamentally honest than the tripe for which they are responsible today." Herschel Brickell, "The Literary Landscape," The North American Review 238, no. 1 (1934): 89-9o.

${ }^{100}$ The quote is from the capsule in the regular "Reader's Reminder List," New Yorker, June 2, 1934, 92. The original review is equally fawning: "The neatest, the most amusing, and at the same time the most thoughtful piece of fundamental muckraking of the last season or so is to be found in James Rorty's new book." Cliffton Fadiman, "Books: Three Reports on the State of the Nation," New Yorker, May 19, 1934, 102

${ }^{101}$ John Shelby, "Scanning New Books," Sarasota Herald, May 14, 1934, 8; Allen Smith, "Bound to Be Read," Piqua Daily Call, May 16, 1934, 4; and Bruce Catton, "A Book a Day," Sandusky Star Journal, May 28, 1934, 6 .

102 Rorty soon had an inauspicious brush with the team of researchers who, in the subsequent decade, would help establish communication research as an interdisciplinary field. It is a remarkable fact that in 1937 Rorty was recruited to work for Paul Lazarsfeld's Princeton Radio Research Project, the Rockefeller Foundation-funded institute that would become, in the 1940s, the Bureau of Applied Social Research at Columbia. Rorty was commissioned to conduct a study for the Project on "Radio Commentators," including listener reactions. Lazarsfeld and one of his associate directors, the psychologist Hadley Cantril, soured on Rorty for a variety of reasons, including work style and the draft itself. Cantril was assigned to resurrect the manuscript, but the "Radio Commentators" monograph was never published and Rorty was, in effect, jettisoned from the Project. The secondary accounts of Rorty's stint do not cite politics as the main site of conflict, though Lazarsfeld-in a memo mounting a qualified defense of the Frankfurt School refugee Theodor Adorno's quixotic (and now-notorious) contribution to the Project-used Rorty as a point of contrast: "It is true that I still have some difficulty in getting $\mathrm{W}$ [Adorno] down to earth but there can be no doubt of his originality and the fruitfulness of his approach. With $\mathrm{R}$ 
[Rorty], I do not even know whether he has produced a new aspect although Had [Cantril] might correct me on this point." Christian Fleck, A Transatlantic History of the Social Sciences: Robber Barons, the Third Reich, and the Invention of Empirical Social Research (New York: Bloomsbury Publishing, 2011), 18384. The whole episode deserves more study, especially since Rorty could be the third major leftist figure-after the well-documented cases of Adorno and the sociologist C. Wright Mills in the mid-1940s - sidelined by the Princeton Radio Research Project/Bureau of Applied Social Research, with all its many radio industry links in this period.

103 Thorstein Veblen, The Higher Learning in America: A Memorandum on the

Conduct of Universities by Business Men

(New York: B. W. Huebsch, 1918).

Advertising, Rorty wrote in the opening chapter, is the "business nobody knows." He continued: "As evidence of this general ignorance, one has only to cite a few of the misapprehensions which have confused the very few contemporary economists, sociologists and publicists who have attempted to treat the subject" $(O M V, 11)$.

$104 O M V, 233$.

$105 O M V, 173-74$. Some of Rorty's special disdain for orthodox economics can be explained by the Veblen counterexample. There is, too, a familial touchstone: Rorty's brother Malcolm, fifteen years his senior, was a prominent economist, AT\&T executive, and defender of laissez-faire. See Gross, Richard Rorty, 44.

${ }^{106} O M V$, chap. 15.

$107 \mathrm{OMV}, 179$.

108 The objectivity critique is an extension of Rorty's broader assault on the professed neutrality of education: "Many teachers, even of the social sciences, are quite unconscious of these [economic] determinants and preserve the confident illusion of 'scientific objectivity' in the very act of asserting creedal absolutes which are obviously a product of social and economic class conditioning" (OMV, 118). See also

174-75, including a long quote from an unpublished Sidney Hook manuscript attacking objectivity.

109 There was, importantly, no such thing as communication research in the United States when Rorty published Our Master's Voice-no organized discipline, not even a label. Yes, the study of communication was already well underway. Indeed, American social science, since its emergence in the late nineteenth century, had fixed the organs of mass communication as objects of study-as tokens of modern social upheaval. In the wake of the Great War-fought, in part, through publicity-scholars and journalists alike took up the question of propaganda and its implications for politics and social life. By the early 1930 a large social-scientific literature had formed, with important studies published in and around Rorty's own 1934 contribution. Still, there was no recognized category called "communication researcher." There were, instead, political scientists, psychologists, sociologists, a handful of economists and others drawn from what were unevenly differentiated disciplines. Only in the subsequent decade-roughly by the end of World War II—did "communication" cohere as an academic formation. Thus the field arrived late, and in a moment of generational turnover. The fight against the Axis powers, and then the new Soviet enemy, yoked the protodiscipline's intellectual agenda to questions of successful persuasion-that is, how to get it working well. By the 1950 os and '6os, communication scholars had finally established a home in journalism schools. In their struggle for legitimacy, they drafted histories of media study that, in the cocksure spirit of the times, cast all pre-war scholarship as naive and impressionistic. One result was amnesia on a field-wide scale: Almost nothing was read or remembered from the 1920 or ' 30 . Even today students of communication learn that there's nothing worth reading before 1945 . So Our Master's Voice was destined to be forgotten, even had its social science contemporaries paid it real heed. The book was ignored twice over, in other words-once in the 1930s and then ever since. 